\title{
Corruption and Decentralized Public Governance
}

\author{
Anwar Shah, World Bank
}

\begin{abstract}
This paper examines the conceptual and empirical basis of corruption and governance and concludes that decentralized local governance is conducive to reduced corruption in the long run. This is because localization helps to break the monopoly of power at the national level by bringing decision making closer to people. Localization strengthens government accountability to citizens by involving citizens in monitoring government performance and demanding corrective actions. Localization as a means to making government responsive and accountable to people can help reduce corruption and improve service delivery. Efforts to improve service delivery usually force the authorities to address corruption and its causes. However, one must pay attention to the institutional environment and the risk of local capture by elites. In the institutional environments typical of some developing countries, when in a geographical area, feudal or industrial interests dominate and institutions of participation and accountability are weak or ineffective and political interference in local affairs is rampant, localization may increase opportunities for corruption. This suggests a pecking order of anti-corruption policies and programs where the rule of law and citizen empowerment should be the first priority in any reform efforts. Localization in the absence of rule of law may not prove to be a potent remedy for combating corruption.
\end{abstract}

World Bank Policy Research Working Paper 3824, January 2006

The Policy Research Working Paper Series disseminates the findings of work in progress to encourage the exchange of ideas about development issues. An objective of the series is to get the findings out quickly, even if the presentations are less than fully polished. The papers carry the names of the authors and should be cited accordingly. The findings, interpretations, and conclusions expressed in this paper are entirely those of the authors. They do not necessarily represent the view of the World Bank, its Executive Directors, or the countries they represent. Policy Research Working Papers are available online at http://econ.worldbank.org. 


\section{Corruption and Decentralized Public Governance}

\section{Anwar Shah, World Bank}

\section{$\underline{\text { Table of Contents }}$}

1. Introduction

2. Corruption and Governance: Fundamental Concepts and Concerns

3. What Drives Corruption?

Conceptual Perspectives

Principal-Agent Model

New Public Management Framework

Neo-Institutional Economics (NIE) Frameworks

Empirical Perspectives

4. Revisiting the Debate on Localization and Corruption

Localization Breeds Corruption

Localization Limits Opportunities for Corruption

5. Corruption and Decentralization: Some Conclusions 


\section{Corruption and Decentralized Public Governance}

\section{Anwar Shah, World Bank}

\section{Introduction}

In their quest for responsive, responsible and accountable public governance, a large number of countries have recently taken steps to re-examine the roles of their various levels of government. This re-examination has resulted in a silent revolution sweeping the globe. This silent revolution is slowly but gradually bringing about rearrangements that embody diverse features of supra-nationalization, confederalization, centralization, provincialization and localization. Note that localization implies home rule, i.e. decision making and accountability for local services at the local level. Fundamental elements of home rule are: local political autonomy with elected officials accountable to local residents; local administrative autonomy - ability for local officials to hire and fire local government employees; and local fiscal autonomy - discretionary ability to raise revenues and authority and flexibility in the use of local resources. The vision of a governance structure that is slowly taking hold through this silent revolution indicates either a gradual shift from unitary constitutional structures to federal or confederal governance for a large majority of people or strengthening local governance under a unitary form of government ( 25 federal and 20 decentralized unitary countries with a combined total of $60.4 \%$ of world population) $)^{1}$. This trend is a current source of concern among academic and policy circles that are worried that localization may adversely affect the quality of public governance through an increase in the incidence of corruption. This paper examines the conceptual and empirical basis of these concerns. Section 2 defines corruption and governance and discusses the importance of current concerns about corruption ${ }^{2}$. Section 3 provides analytical perspectives on corruption. This is followed by a discussion in subsequent sections (sections 4-5) of special concerns about corruption under decentralized governance and a synthesis of empirical evidence on this subject. A final section presents some conclusions. 


\section{Corruption and Governance: Fundamental Concepts and Concerns}

Corruption is defined as exercise of official powers against public interest or the abuse of public office for private gains. Public sector corruption is a symptom of failed governance. Here, we define "governance" as the norms, traditions and institutions by which power and authority in a country is exercised - including the institutions of participation and accountability in governance and mechanisms of citizens' voice and exit and norms and networks of civic engagement; the constitutional-legal framework and the nature of accountability relationships among citizens and governments; the process by which governments are selected, monitored, held accountable and renewed or replaced; and the legitimacy, credibility and efficacy of the institutions that govern political, economic, cultural and social interactions among citizens themselves and their governments.

Concern about corruption - the abuse of public office for private gain - is as old as the history of government. In 350 B.C.E., Aristotle suggested in The Politics that “. . . to protect the treasury from being defrauded, let all money be issued openly in front of the whole city, and let copies of the accounts be deposited in various wards." In recent years, concerns about corruption have mounted in tandem with growing evidence of its detrimental impact on development (see World Bank, 2004). Corruption is shown to adversely affect GDP growth (Mauro, 1995, Abed and Davoodi 2000). Corruption has been shown to lower the quality of education (Gupta, Davoodi and Tiongson, 2000), public infrastructure (Tanzi and Davoodi 1997) and health services (Tomaszewska and Shah, 2000, Triesman, 2000), and to adversely affect capital accumulation. It reduces the effectiveness of development aid and increases income inequality and poverty (Gupta, Davoodi and Alonso-Terme, 1998). Bribery, often the most visible manifestation of public sector corruption, harms the reputation of and erodes trust in the state. As well, poor governance and corruption have made it more difficult for the poor and other disadvantaged groups, such as women and minorities, to obtain public services. Macroeconomic stability may also suffer when, for example, the allocation of 
debt guarantees based on cronyism, or fraud in financial institutions, leads to a loss of confidence by savers, investors, and foreign exchange markets. For example, the Bank of Credit and Commerce International (BCCI) scandal, uncovered in 1991, led to the financial ruin of Gabon's pension system and the corrupt practices at Mehran Bank in the Sindh Province of Pakistan in the mid-1990s led to a loss of confidence in the national banking system in Pakistan.

Although statistics on corruption are often questionable, the available data suggest that it accounts for a significant proportion of economic activity. For example, in Kenya, "questionable" public expenditures noted by the Controller and Auditor General in 1997 amounted to 7.6 percent of GDP. In Latvia, a World Bank survey found that more than 40 percent of Latvian households and enterprises agreed that "corruption is a natural part of our lives and helps solve many problems." In Tanzania, service delivery survey data suggest that bribes paid to officials in the police, courts, tax services, and land offices amounted to 62 percent of official public expenditures in these areas. In the Philippines, the Commission on Audit estimates that $\$ 4$ billion is diverted annually because of public sector corruption (see Shah and Schacter, 2004). Moreover, a study by Tomaszewska and Shah (2000) on the ramifications of corruption for service delivery concludes that an improvement of one standard deviation in the ICRG corruption index leads to a 29 percent decrease in infant mortality rates, a 52 percent increase in satisfaction among recipients of public health care, and a 30-60 percent increase in public satisfaction stemming from improved road conditions.

As a result of this growing concern, there has been universal condemnation of corrupt practices, leading to the removal of some country leaders. Moreover, many governments and development agencies have devoted substantial resources and energies to fighting corruption in recent years. Even so, it is not yet clear that the incidence of corruption has declined perceptibly, especially in highly corrupt countries. The lack of significant progress can be attributed to the fact that many programs are simply folk remedies or "one size fits all" approaches and offer little chance of success. For programs to work, 
they must identify the type of corruption they are targeting and tackle the underlying, country-specific causes, or "drivers," of dysfunctional governance.

\section{The many forms of corruption}

Corruption is not manifested in one single form; indeed it typically takes at least four broad forms.

Petty, administrative or bureaucratic corruption. Many corrupt acts are isolated transactions by individual public officials who abuse their office, for example, by demanding bribes and kickbacks, diverting public funds, or awarding favors in return for personal considerations. Such acts are often referred to as petty corruption even though, in the aggregate, a substantial amount of public resources may be involved.

Grand corruption. The theft or misuse of vast amounts of public resources by state officials - usually members of, or associated with, the political or administrative elite-constitutes grand corruption.

State or regulatory capture and influence peddling. Collusion by private actors with public officials or politicians for their mutual, private benefit is referred to as state capture. That is, the private sector "captures" the state legislative, executive, and judicial apparatus for its own purposes. State capture coexists with the conventional (and opposite) view of corruption, in which public officials extort or otherwise exploit the private sector for private ends.

Patronage/paternalism and being a "team player". Using official position to provide assistance to clients having the same geographic, ethnic and cultural origin so that they receive preferential treatment in their dealings with the public sector including public sector employment. Also providing the same assistance on a quid pro quo basis to colleagues belonging to an informal network of friends and allies. 
It is also known that corruption is country-specific; thus, approaches that apply common policies and tools (that is, one-size-fits-all approaches) to countries in which acts of corruption and the quality of governance vary widely are likely to fail. One needs to understand the local circumstances that encourage or permit public and private actors to be corrupt.

Finally, we know that if corruption is about governance and governance is about the exercise of state power, then efforts to combat corruption demand strong local leadership and ownership if they are to be successful and sustainable.

\section{What drives corruption?}

Public sector corruption, as a symptom of failed governance, depends on multitude of factors such as the quality of public sector management, the nature of accountability relations between the government and citizens, the legal framework and the degree to which public sector processes are accompanied by transparency and dissemination of information. Efforts to address corruption that fail to adequately account for these underlying "drivers" are unlikely to generate profound and sustainable results. To understand these drivers, a conceptual and empirical perspective is needed to understand why corruption persists and what can be a useful antidote. At the conceptual level, a number of interesting ideas have been put forward ${ }^{3}$. These ideas can be broadly grouped together in three categories (a) Principal- agent or agency models; (b) new public management perspectives; and (c) neo-institutional economics frameworks.

\section{Conceptual Perspectives}

\section{Principal- Agent Models}

This is the most widely used modelling strategy. A common thread in these models is that the government is led by a benevolent dictator, the principal, who aims to motivate government officials (agents) to act with integrity in the use of public resources (see 
Becker, 1968, Becker and Stigler, 1974, Banfield 1975, Rose Ackerman 1975, 1978, Klitgaard 1988, 1991, Becker 1983). One such view, the so-called crime and punishment model by Gary Becker (1968), states that self-interested public officials seek out or accept bribes so long as the expected gains from corruption exceed the expected costs (detection and punishment) associated with corrupt acts. Thus, according to this view, corruption could be mitigated by (a) reducing the number of transactions over which public officials have discretion; (b) reducing the scope of gains from each transaction; (c) increasing the probability for detection; and (d) increasing the penalty for corrupt activities. Klitgaard (1988) restates this model to emphasize the unrestrained monopoly power and discretionary authority of government officials. According to him, corruption equals monopoly plus discretion minus accountability. To curtail corruption under this framework, one has to have a rules-driven government with strong internal controls and with little discretion to public officials. This model gained wide acceptance in public policy circles and served as a foundation for empirical research and policy design to combat administrative, bureaucratic, or petty corruption. Experience in highly corrupt countries, however, contradicts the effectiveness of such an approach as the rules enforcers themselves add extra burden of corruption and lack of discretion is also thwarted by collusive behavior of corruptors. In fact lack of discretion is often cited as a defense by corrupt officials who partake in corruption as part of a vertically well-knit network enjoying immunity from prosecution.

Another variant of principal-agent models integrates the role of legislators and elected officials in the analysis. In this variant, high level government officials -represented by legislators or elected public officials- institute or manipulate existing policy and legislation in favor of particular interest groups - representing private sector interests and entities or individual units of public bureaucracy competing for higher budgets- in exchange of rents or side payments. In this framework, legislators weigh the personal monetary gains from corrupt practices and improved chances of re-election against the chance of being caught, punished and losing an election with a tarnished reputation. Factors affecting this decision include campaign financing mechanisms, information access by voters, the ability of citizens to vote out corrupt legislators, the degree of 
political contestability, electoral systems, democratic institutions and traditions and institutions of accountability in governance. Examples of such analyses include: RoseAckerman (1978), Andvig \& Moene (1990), Grossman \& Helpman (1994), Flatters \& Macleod (1995), Chand \& Moene (1997), Van Rijckeghem \& Weder, (1998), Acconcia D'Amato \& Martina (2003). This conceptual framework is useful in analyzing political corruption or state capture.

There is a fine line dividing theoretical models that focus on the effects of localization on corruption and those that analyze the decentralization of corruption within a multi-tier hierarchy from an "industrial organization of corruption" type of framework. In the latter group a distinction is made between "top-down corruption" -where corrupt high levels buy lower levels by sharing a portion of gains- and "bottom-up corruption" -where low level officials share their own collected bribes with superior levels to avoid detection or punishment. The former phenomenon is more likely to exist in a federal system of governance where powers may be shared among various orders of government and the alter is more likely to prevail under unitary or centralized forms of governance or dictatorial regimes. The impact of governance on the corruption networks is an interesting yet unresearched topic. Tirole (1986) analyzed one aspect of this network by means of a three-tier principal-supervisor-agent model (see also Guriev 1999). This extension of a conventional principal-agent model assists in drawing inferences regarding the type of corrupt relations that could evolve under a three-tier unitary government structure. These inferences are highly sensitive to underlying assumptions regarding principal-agent relationships under a multi-tiered system of governance (four-tier hierarchies are modeled by Carillo 2000, Bac \& Bag 1998). In Guriev's three-tier hierarchy model the mid level bureaucrat supervises the agent and reports to the principal. In comparing the characteristics of equilibria with top-bottom-and all level corruption Guriev concludes that top-level corruption "is not efficient, as it redistribute rents in favor of agents, and therefore makes it more attractive for potential entrants" (p.2) and thereby leading to higher total corruption. 
Shleifer and Vishny (1993) utilize conventional industrial organization theory model and conclude that decentralization is likely to increase corruption. In this model, government bureaucracies and agencies act as monopolists selling complimentary governmentproduced goods which are legally required for private sector activity. The main idea behind the model is that under centralized corruption bureaucracies act like a joint monopoly, whereas under decentralized corruption bureaucracies behave as independent monopolies. When bureaucracies act as independent monopolies, they ignore the effects of higher prices on the overall demand for a good and hence drive up the cumulative bribe burden.

Waller, Verdier and Gardner (2002) define decentralized corruption as a system in which higher level officials collect a fixed amount of bribe income from each of the bureaucrats that take bribes, without mandating on the bribe size that the bureaucrats charge. On a centralized system, on the contrary, bribe size is determined by the higher level of government which collects them bureaucrats and redistributes it among them after keeping a share. Waller et al. posit that decentralized corruption leads to lower levels of total corruption in the economy (lower spread), higher levels of bribe per entrepreneur (higher depth), and a smaller formal sector vis-a-vis a centralized corruption equilibrium. Yet, these results vary widely for specific 'regimes' in the model - when given parameters satisfy key conditions - for instance, for high-enough wages and monitoring systems, centralized corruption may reduce total corruption and expand the formal economy.

While previously discussed studies centered on the organizational structure of corruption, Ahlin (2001) differs by concentrating on the alternative effects of different types of decentralization, and doing so from a horizontal, as opposed to hierarchical, perspective. In this model, a country is divided in regions, each with a given number of independent power groups. Bureaucratic decentralization affects the political organization in a region by increasing the number of power groups or bureaucracies, while the number of jurisdictions captures the degree of regional decentralization (i.e. having a single region and bureaucracy would reflect the maximum degree of centralization). Ahlin's theoretical 
results suggest that corruption is determined by mobility of economic agents across regions. Under the assumption of no interregional mobility, corruption increases with the degree of bureaucratic decentralization but is independent of the degree of regional decentralization, whereas for perfect interregional mobility corruption decreases with regional decentralization and is independent of bureaucratic decentralization. A key intuition of the model is that corrupt bureaucrats fail to internalize the costs of increases in bribe-charges imposed on other bureaucrats.

Arikan (2004) uses a tax competition framework to examine localization-corruption links. In his model, corruption is measured as the proportion of tax revenue appropriated by bureaucrats, whereas decentralization is captured by the number of jurisdictions competing for a mobile tax base. Local governments decide on the levels of tax rates and corrupt earnings in order to maximize a weighted sum of corrupt earnings and citizen's utility. In this framework higher degree of decentralization is expected to lead to lower levels of corruption.

Bardhan and Mookherjee (2000a) shed light upon the determinants of capture of the democratic process. Not surprisingly, they conclude that the extent of relative capture is ambiguous and context specific. Bardhan et al. find that the extent of capture at the local level depends on the degree of voter awareness, interest group cohesiveness, electoral uncertainty, electoral competition and the heterogeneity of inter-district income inequality. A key assumption of this model is that the degree of political awareness is correlated to education and socioeconomic position; in particular, that the fraction of informed voters in the middle income class is lower or equal than rich, and higher than that of the poor. Uninformed voters are swayed by campaign financing, whereas informed voters favor the party platform that maximizes their own-class utility. The outcome of local and national elections in terms of policy platforms, will coincide under four assumptions: i) all districts have the same socioeconomic composition, and swings among districts (particular district specific preferences for one of two political parties) are perfectly correlated; ii) national elections are majoritarian; iii) there is an equal proportion of informed voters in local and national elections; and iv) the proportion of 
rich who contribute to their lobby is equal at the national and local levels -rich are as well organized nationally as locally. Alternatively, capture will be higher at the local level if conditions (iii) and (iv) fail. That is, if the proportion of informed voters is lower at the national levels and the rich are less organized nationally than they are locally. On the contrary, greater electoral uncertainty at the local level due to differences in the electoral competition imply lower capture at the local level. This would be the case if, for example, swings are not identical but rather drawn from the same distribution across districts - assuming this distribution satisfies a regularity condition- heterogeneity on swings will favor different parties implying less capture of the nationally dominant party. In conclusion, no definitive conclusions can be drawn regarding corruption and the centralization-decentralization nexus from the agency type conceptual models. These models simply reaffirm that the incidence of corruption is context dependent and therefore cannot be uncovered by generalized models.

\section{New Public Management Frameworks}

The new public management (NPM) literature, on the other hand, points to a more fundamental discordance among the public sector mandate, its authorizing environment and the operational culture and capacity. According to NPM, this discordance contributes to government acting like a runaway train and government officials indulging in rent-seeking behaviors with little opportunity for citizens to constrain government behavior. This viewpoint calls for fundamental civil service and political reforms to create a government under contract and accountable for results. Public officials will no longer have permanent rotating appointments but instead they could keep their jobs as long as they fulfilled their contractual obligations (see Shah, 1999, 2005).

The new public management (NPM) paradigms have clear implications for the study of localization and corruption as it argues for contractual arrangements in provision of public services. Such a contractual framework may encourage competitive service delivery through outsourcing, purchaser-provider split under a decentralized structure of governance. The NPM goals are harmonious with localization as greater accountability 
for results reinforces government accountability to citizens through voice and exit mechanisms. Conceptually, therefore, the NPM is expected to reduce opportunities for corruption (see Shah 1999, 2005, Von Maravic 2003). Andrews and Shah (2005) integrate these two ideas in a common framework of citizen-centered governance. They argue that citizen empowerment holds the key to enhanced accountability and reduced opportunities for corruption.

Others disagree with such conclusions and argue that that NPM could lead to higher corruption as opposed to greater accountability. This may happen because the tendering for service delivery and separation of purchasers from providers may lead to increased rent seeking behaviors and enhanced possibilities for corruption (Batley 1999, Von Maravic, 2003). Further some argue that decentralized management leads to weaker vertical supervision from higher levels and the inadequacy of mechanisms to exert controls over decentralized agencies (Scharpf, 1997). This loss in vertical accountability is seen as a source of enhanced opportunities for corruption. Of course, this viewpoint simply neglects potential gains from higher horizontal accountability.

\section{Neo-Institutional Economics (NIE) Frameworks}

Finally, neo-institutional economics (NIE) presents a refreshing perspective on the causes and cures of corruption. The NIE approach argues that corruption results from opportunistic behavior of public officials as citizens are either not empowered or face high transaction costs to hold public officials accountable for their corrupt acts. The NIE treats citizens as principals and public officials as agents. The principals have bounded rationality - they act rationally based upon the incomplete information they have. In order to have a more informed perspective on public sector operations, they face high transaction costs in acquiring and processing the information. On the other hand, agents (public officials) are better informed. This asymmetry of information allows agents to indulge in opportunistic behavior which goes unchecked due to high transactions costs faced by the principals and a lack of or inadequacy of countervailing institutions to enforce accountable governance ${ }^{4}$. Thus corrupt countries have inadequate mechanisms 
for contract enforcement, weak judicial systems and inadequate provision for public safety. This raises the transactions costs in the economy further raising the cost of private capital as well as the cost of public service provision. The problem is further compounded by path dependency (i.e. a major break with the past is difficult to achieve as any major reforms are likely to be blocked by influential interest groups), cultural and historical factors and mental models where those who are victimized by corruption feel that attempts to deal with corruption will lead to further victimization, with little hope of corrupt actors being brought to justice. These considerations lead principals to the conclusion that any attempt on their part to constrain corrupt behaviors will invite strong retaliation from powerful interests. Therefore, citizen empowerment (e.g. through devolution, citizens' charter, bill of rights, elections and other forms of civic engagement) assumes critical importance in combating corruption because it may have a significant impact on the incentives faced by public officials to be responsive to public interest.

\section{Empirical Perspectives}

The empirical literature on this subject lends support to the NIE perspective elaborated above but goes beyond to identify some key drivers based on in-depth country studiesincluding a recent World Bank look at Guatemala, Kenya, Latvia, Pakistan, Philippines, and Tanzania - and econometric studies of developing, transition, and industrial countries (see World Bank 2004, Tomaszewska and Shah, 2000, Gurgur and Shah, 2002 and Huther and Shah, 2000). The six country case studies by the World Bank examined the root causes of corruption and evaluated the impact of World Bank efforts to reduce corruption in each country. The key corruption drivers identified by these studies include:

\section{- The legitimacy of the state as the guardian of the "public interest" is contested.}

In highly corrupt countries, there is little public acceptance of the notion that the role of the state is to rise above private interests to protect the broader public interest.

"Clientelism"- public office holders focusing on serving particular client groups linked to them by ethnic, geographic or other ties - shapes the public landscape and creates 
conditions that are ripe for corruption. The line between what is "public" and what is "private" is blurred so that abuse of public office for private gain is a routine occurrence.

- The rule of law is weakly embedded. Public sector corruption thrives where laws apply to some but not to others, and where enforcement of the law is often used as a device for furthering private interests rather than protecting the public interest. A common symbol of the breakdown of the rule of law in highly corrupt countries is the police acting as law-breakers rather than law enforcers-for example, stopping motorists for invented traffic violations as an excuse for extracting bribes. As well, the independence of the judiciary - a pillar of the rule of law-is usually deeply compromised in highly corrupt countries.

- Institutions of participation and accountability are ineffective. In societies where the level of public-sector corruption is relatively low, one normally finds strong institutions of participation and accountability that control abuses of power by public officials. These institutions are either created by the state itself (for example, electoral process, citizens' charter, bill of rights, auditors-general, the judiciary, the legislature) or arise outside of formal state structures (for example, the news media and organized civic groups). There are glaring weaknesses in institutions of participation and accountability in highly corrupt countries.

- The commitment of national leaders to combating corruption is weak. Widespread corruption endures in the public sector when national authorities are either unwilling or unable to address it forcefully. In societies where publicsector corruption is endemic, it is reasonable to suspect that it touches the highest levels of government, and that many senior office-holders will not be motivated to work against it.

\section{How to formulate a strategy}

So what can policymakers do to combat corruption? Experience strongly suggests that the answer lies in taking an indirect approach and starting with the root causes. To understand why, it is helpful to look at a model that divides developing countries into three broad categories — "high," "medium" and "low" — reflecting the incidence of 
corruption. The model also assumes that countries with "high" corruption have a "low" quality of governance, those with "medium" corruption have "fair" governance, and those with "low" corruption have "good" governance (see table 1).

Table 1. One Size Does Not Fit All: Effective anti-corruption policies specify a pecking order of reforms based upon a recognition of broader institutional environment in each country

\begin{tabular}{|c|c|l|}
\hline $\begin{array}{c}\text { Incidence of } \\
\text { corruption }\end{array}$ & $\begin{array}{c}\text { Quality of } \\
\text { governance }\end{array}$ & \multicolumn{1}{|c|}{ Priorities of anticorruption efforts } \\
\hline High & Poor & $\begin{array}{l}\text { Establish rule of law, strengthen institutions of } \\
\text { participation and accountability; establish citizens' } \\
\text { charter, limit government intervention, implement } \\
\text { economic policy reforms }\end{array}$ \\
\hline Medium & Fair & $\begin{array}{l}\text { Decentralize and reform economic policies and public } \\
\text { management and introduce accountability for results }\end{array}$ \\
\hline Low & Good & $\begin{array}{l}\text { Establish anticorruption agencies; strengthen financial } \\
\text { accountability; raise public and official awareness; } \\
\text { anti-bribery pledges, conduct high-profile prosecutions }\end{array}$ \\
\hline
\end{tabular}

What this model reveals is that because corruption is itself a symptom of fundamental governance failure, the higher the incidence of corruption, the less an anti-corruption strategy should include tactics that are narrowly targeted to corrupt behaviors and the more it should focus on the broad underlying features of the governance environment. For example, support for anti-corruption agencies and public awareness campaigns is likely to meet with limited success in environments where corruption is rampant and the governance environment deeply flawed. In fact, in environments where governance is weak, anti-corruption agencies are prone to being misused as tools of political victimization. These types of interventions are more appropriate to a "low" corruption setting, where one can take for granted (more or less) that the governance fundamentals are reasonably sound and that corruption is a relatively marginal phenomenon. 
The model also suggests that where corruption is high (and the quality of governance is correspondingly low), it makes more sense to focus on the underlying drivers of malfeasance in the public sector - for example, by building the rule of law and strengthening institutions of accountability. Indeed, a lack of democratic institutions (a key component of accountability) has been shown to be one of the most important determinants of corruption (Gurgur and Shah 2002). When Malaysia adopted a "client's charter" in the early 1990s that specified service standards and citizens recourse in the event of non-compliance by government agencies, it helped reorient the public sector toward service delivery and transform the culture of governance (Shah, 1999, 2005).

In societies where the level of corruption lies somewhere in between the high and low cases, it may be advisable to attempt reforms that assume a modicum of governance capacity - such as trying to make civil servants more accountable for results, bringing government decision-making closer to citizens through decentralization, simplifying administrative procedures, and reducing discretion for simple government tasks such as the distribution of licenses and permits.

\section{Insights into past failures}

With this model in mind, it is not hard to understand why so many anti-corruption initiatives have met with so little success. Take for example the almost universal failure of wide-ranging media awareness campaigns, and of seminars and workshops on corruption targeted to government officials, parliamentarians and journalists. As the model shows, this outcome would be expected in countries with weak governance, where corruption is openly practiced but neither the general public nor honest public officials feel empowered to take a stand against it and even fear being victimized. On the other hand, awareness campaigns would be expected to have a positive impact in countries where governance is fair or good and the incidence of corruption is low.

Decentralization provides a further illustration of the importance of understanding the circumstances in which corruption occurs. There is indeed evidence that decentralization 
can be an effective antidote to corruption because it increases the accountability of public authorities to citizens (for additional references and evidence, see Gurgur and Shah (2002) and Shah, Thompson and Zou (2004)). On the other hand, decentralization creates hundreds of new public authorities, each having powers to tax, spend and regulate that are liable to being abused in environments where governance is weak. As the Bank's analysis of the Philippines in the 1990s has shown, decentralization may multiply rather than limit opportunities for corruption if it is implemented under the wrong circumstances. This issue is the central theme of this paper and it is analyzed further in the following sections.

As for raising civil service salaries and reducing wage-compression — the ratio between the salaries of the highest- and lowest-paid civil servants in a given country - again, the model provides some insights. The evidence suggests that in environments where governance is weak, wage-based strategies are not likely to have a significant impact on civil service corruption (see Huther and Shah, 2000 for references). Moreover, reducing wage compression may even encourage corruption if public sector positions are viewed as a lucrative career option. For instance, in corrupt societies public positions are often purchased by borrowing money from family and friends. Raising public sector wages simply raises the purchase price and subsequent corruption efforts to repay loans.

How about the establishment of "watchdog" agencies — something most developing countries have done - with a mandate to detect and prosecute corrupt acts? Here, too, the governance-corruption nexus is key. Watchdog agencies have achieved success only in countries where governance is generally good, such as Australia and Chile. In weak governance environments, however, these agencies often lack credibility and may even extort rents. In Kenya, Malawi, Sierra Leone, Tanzania, Uganda and Nigeria, for example, anti-corruption agencies have been ineffective. In Tanzania, the government's Prevention of Corruption Bureau produces only about six convictions a year, mostly against low-level functionaries, in a public sector environment rife with corruption. In Pakistan, the National Accountability Bureau does not even have a mandate to investigate corruption in the powerful and influential military. Ethics offices and ombudsmen have 
had no more success than anticorruption agencies in countries where governance is poor (see Huther and Shah, 2000 and Shah and Schacter, 2004).

\section{Revisiting the debate on localization and corruption}

A brief review of the corruption literature presented above serves as a useful background to the debate on corruption and decentralization. In the following sections, we briefly review the arguments and the evidence on both side of the debate and then draw some conclusions based upon the simple analytical model presented earlier.

\section{Localization breeds corruption}

A number of arguments have been advanced to support the notion that corruption increases with localization. A few of these are summarized below.

a) Personalism. Vito Tanzi (1995) argued that localization brings officials in close contact with citizens. This promotes personalism and reduces professionalism and arms length relationships. Personalism in his view breeds corruption as officials pay greater attention to individual citizen needs and disregard public interest. Further, higher degree of discretion at the local level and long tenure of local officials making it easier to establish unethical relationships (Prud'homme 1995).

b) Weak monitoring and vertical controls. Impediments to corrupt practices also decrease as local politicians and bureaucrats collude to advance narrow self-interests while the effectiveness of auditing agencies and monitoring from the central level wanes (Prud'homme 1995). Localization may increase the motivation for corruption among public officials by creating an impression that they are subject to lower monitoring, control and supervision.

c) Fiscal decentralization and overgrazing. Triesman argues that decentralized federal systems tend to have higher corruption ratings due to (a) their larger size; (b) 
more likely to have separate police forces at both central and sub-national levels (which increases corruption due to overgrazing) and their greater propensity to have a regionally elected upper house of parliament with veto power (which also may increase corruption as regional governments may buy off these veto-players or have greater leverage to protect their ill-gotten gains). Using cross country regression analysis Treisman (1999, 2000, 2002) presents empirical evidence that support the existence of this negative relationship. Treisman's empirical results, however, are sensitive to the inclusion of other variables in the equation and may have omitted variables bias in view of a lack of underlying framework for corruption.

d) Political decentralization and lack of discipline. Political decentralization is seen as a cascading system of bribes by Shleifer and Vishny (1993). They note that "to invest in a Russian company, a foreigner must bribe every agency involved in foreign investment including the foreign investment office, the relevant industrial ministry, the finance ministry, the executive branch of the local government, the legislative branch, the central bank, the state property bureau, and so on.” (p. 615). In the same vain, Bardhan (1997) and Blanchard and Shleifer (2000) [B\&S] have argued that political centralization leads to lower levels of corruption. B\&S sustain that political decentralization is seen as a source of corruption in Russia but not China. This conclusion emerges from the contrasting role of local governments in their relations with local enterprises observed in China and Russia. In China, local governments have provided a supporting role whereas in Russia, local governments have stymied the growth of new firms through taxation, regulation and corruption. The authors note that behavior of Russian local governments can be explained by (a) state capture by old firms, leading local governments to protect them from competition and (b) rent seeking behavior of local officials discouraging new firms to enter. The authors attribute this contrasting experience to presence of political decentralization in Russia and its absence in China. They argue that political centralization in China contributes to party discipline which in turn reduces the risk of local capture and corruption. However, B\&S analysis does not pay sufficient attention to local-enterprise relations in the two countries. Local enterprises in China are owned and run by local governments and even deliver local services such as education, health and 
transportation in addition to their economic functions. Thus local enterprises are part and parcel of the local government. In Russia, on the other hand, a mixed pattern of these relationships has begun to emerge. Therefore, the contrasting experience of the local governments may better be explained by agency problems rather than by political decentralization. In fact the weakening of party discipline through the emergence of powerful local leaders may be contributing to growth of local industry as the strong arm of central planning is held at bay by these leaders.

e) Interest group capture. Opportunities for corruption increase due to a greater influence of interest groups at the local level (Prud'homme 1995). In this regard, Bardhan and Mookherjee (2000a) argue that the probability of capture by local interest groups could be greater at the local level if, for example, interest group cohesiveness (fraction of the richest class that contribute to lobby) is higher, or the proportion of informed voters is lower at the local level. Lower levels of political awareness at the local level and less coverage of local elections by media may also impair local democracy and lead to higher capture. The notion of capture at the local levels due to weaknesses of the democratic system has also been raised by Shah (1998). Concerns about risks of local capture are also expressed in a recent World Bank Study (World Bank, 2004). The study argues that decentralization may increase opportunities for corruption in some developing countries where interference in public administration is the norm, merit culture and management systems in the civil service are weak and institutions of participation and accountability are ineffective. The issue is significant, for example, in Pakistan and Philippines and also relevant to Guatemala and Tanzania where more limited decentralization is underway. Pakistan has launched a decentralization program involving the creation of 7,000 local and sub-national governments. Given systemic politicization of public services in Pakistan, decentralization may intensify rather than reduce pressures for political/bureaucratic collusion, although this may be further mitigated by further administrative decentralization, giving elected local officials the power to, hire, fire and set terms of employment of civil servants in their jurisdiction. Note that administration decentralization in areas under feudal influence is likely to exacerbate the corruption concerns. Identical concerns are pertinent in Philippines, where legislation in 1991 
devolved to regions and localities powers to provide services and raise revenues. A study of local government procurement in the Philippines revealed that (see Tapales, 2001, p.21): “contractors admit to paying mayors of the towns where they have projects, because, they say, the officials can delay the work by withholding necessary permits or harassing the workers. Municipal mayors get seven percent while the barangay (village) captain is given three percent. The heads of implementing agencies - usually the district, municipal or city engineer - get about 10 percent."

The World Bank study is concerned with the effect of decentralization on corruption when there is a local capture by political and bureaucratic elites. There is little disagreement in the literature that in such a situation, localization without fundamental electoral and land reforms, is likely to increase corruption. On the contrary, the perception of localization as a breeding ground for corruption in the presence of democratic participation and accountability, is neither grounded in theory nor in evidence.

\section{Localization Limits Opportunities for Corruption}

Localization's ability to curtail corruption opportunities has been commonly based on the potential for greater accountability when the decision making is closer to the people. This line of thought is supported from the following perspectives:

a) Competition among local governments for mobile factors of production reinforces the accountability culture. Such enhanced accountability has the potential to reduce corruption (Weingast, 1995, Arikan 2000).

b) Exit and voice mechanisms at the local level. There is a general agreement in the literature that localization can open up greater opportunities for voice and choice thereby making the public sector more responsive and accountable to citizens-voters. Furthermore, due to regional heterogeneity of political preferences localization may reduce the range of potential capture by a unique nationally dominant party. 
c) Higher levels of information. Seabright (1996) argues that accountability is always better at the local level, since local citizens who are better informed about government performance can vote these governments out of office. Under centralization people vote for parties or candidates partly on the basis of performance in other regions and on issues of national interest. As a result accountability is defused and potential for corruption increases. Bardhan and Mookherjee (2000b) also argue that decentralization of the delivery of anti-poverty programs in developing countries promotes costeffectiveness and reduces corruption, owing to the superior access of local governments to information on local costs and needs.

\section{d) Lower expected gains from corruption but greater probability of detection}

and punishment. Administrative decentralization causes a loss in control to higher levels, thus curbing their incentives to monitor and detect corrupt activities. However, it also lowers the expected gains from corruption as, following decentralization, the number of individuals who are in charge of a single decision is reduced. It is then more likely that corrupt agents are called to bear the consequences of their actions. This line of thought complements those put forward by Carbonara (1999); who concludes that decentralization although creating agency problems inside an organization can help in controlling corruption; and Wildasin (1995), who argues that local officials with limited powers have little scope to engage in massive corruption.

e) Political decentralization. Ahlin (2000) has argued that deconcentration has the potential to increase corruption, whereas political decentralization has the potential to contain it due to interjurisdictional competition. This may result from a reduction in the information asymmetry between bureaucrats and the politicians that appoint them vis a vis a politically centralized systems. Crook and Manor (2000) examined the process of political decentralization in India (Karnatka state), Bangladesh, Cote d'Ivoire and Ghana and find that such decentralization leads to enhanced transparency. With this enhanced transparency, ordinary citizen become better aware of government's successes and failures and they may perceive the government institutions more corrupt than the perception they had before. They observed that in Karnatka, India, political 
decentralization substantially reduced the amount of public funds diverted by powerful individuals. However, since citizens were not aware of these diversions, they concluded that corruption had increased. Crook and Manor based upon evidence from Karnatka conclude that political decentralization reduces grand theft but increases petty corruption in the short run but in the long run both may go down. Olowu (1993) also considers political centralization as a root cause of endemic corruption in Africa. Fiszbein (1997) based upon a review of political decentralization in Colombia concludes that competition for political office opened the door for responsible and innovative leadership that in turn became the driving force behind capacity building, improved service delivery and reduced corruption at the local level.

f) Administrative decentralization. A few studies show that administrative decentralization reduces corruption. Wade (1997) finds that over-centralized top down management accompanied by weak communication and monitoring systems contributes to corruption and poor delivery performance for canal irrigation in India. Kuncoro (2000) finds that with administrative decentralization in Indonesia, firms relocated to areas with lower bribes.

g) Fiscal decentralization. Huther and Shah (1998) using international crosssection and time series data find that fiscal decentralization is associated with enhanced quality of governance as measured by citizen participation, political and bureaucratic accountability, social justice, improved economic management and reduced corruption. Arikan (2004) reconfirms the same result. De Mello and Barenstein (2001) based upon cross-country data conclude that tax decentralization is positively associated with improved quality of governance. Fisman and Gatti (2002) find a negative relations between fiscal decentralization and corruption. Gurgur and Shah (2002) is the only study providing a comprehensive theoretical and empirical framework on the root causes of corruption. They identify major drivers of corruption in order to isolate the effect of decentralization. In a sample of industrial and non-industrial countries, lack of service orientation in the public sector, weak democratic institutions, economic isolation (closed economy), colonial past, internal bureaucratic controls and centralized decision making 
are identified as the major causes of corruption. For a non-industrial countries sample, drivers for corruption are lack of service orientation in the public sector, weak democratic institutions and closed economy. Decentralization reduces corruption but has a greater negative impact on corruption in unitary countries than in federal countries. They conclude that decentralization is confirmed to support greater accountability in the public sector and reduced corruption.

In all, a small yet growing body of theoretical and empirical literature confirms that localization offers significant potential in bringing greater accountability and responsiveness to the public sector at the local level and reducing the incidence of grand corruption.

\section{Corruption and Decentralization: Some Conclusions}

Power corrupts and absolute power corrupts absolutely. Localization helps to break the monopoly of power at the national level by bringing decision making closer to people. Localization strengthens government accountability to citizens by involving citizens in monitoring government performance and demanding corrective actions. Localization as a means to make government responsive and accountable to people can help reduce corruption and improve service delivery. Efforts to improve service delivery usually force the authorities to address corruption and its causes. However, one must pay attention to the institutional environment and the risk of local capture by elites. In the institutional environments typical of some developing countries, when in a geographical area, feudal and industrial interests dominate and institutions of participation and accountability are weak or ineffective and political interference in local affairs is rampant, localization may increase opportunities for corruption. This suggests a pecking order of anti-corruption policies and programs as highlighted in Table 1. Thus rule of law and citizen empowerment should be the first priority in any reform efforts. Localization in the absence of rule of law may not prove to be a potent remedy for combating corruption. 
Anwar Shah is Lead Economist and Program Leader in Public Sector Governance in the World Bank Institute. He is grateful to Javier Arze for excellent research assistance for this paper. This paper is forthcoming in the Ahmad, E. and G. Brosio, editors (2006), Handbook of Fiscal Federalism, Edward Elgar Press, New York. Comments on this paper may be addressed to: ashah@worldbank.org

\section{References:}

Abed, George T. and Hamid Davoodi (2000). "Corruption, Structural Reforms, and Economic Performance in the Transition Economies." International Monetary Fund Working Paper No. 00/132.

Acconcia, Antonio, Marcello D'Amato and Riccardo Martina (2003). "Corruption and Tax Evasion with Competitive Bribes." CSEF Working Papers (University of Salerno, Italy: Centre for Studies in Economics and Finance) 112.

Ades, Alberto and Rafael Di Tella (1997): "National Champions and Corruption: Some Unpleasant Interventionist Arithmetic.” The Economic Journal 107:1023-1042.

Advig, Jens Chr. and Karl O. Moene (1990). "How Corruption May Corrupt.” Journal of Economic Behavior and Organization 13:63-76.

Ahlin, Christian (2001). "Corruption: Political determinants and Macroeconomic effects." Working Paper (Vanderbilt University: Department of Economics) No. 01-W26. , 2000. “Corruption, Aggregate Economic Activity and Political Organization.” University of Chicago, processed.

Andrews, Matthew and Anwar Shah. (2005) "Towards Citizen-centered Local Budgets in Developing Countries.” In Shah, Anwar, editor, Public Expenditure Analysis. Washington D.C.: World Bank.

Arikan, Gulsun (2004). "Fiscal Decentralization: A Remedy for Corruption?” International Tax and Public Finance 11:175-1995. , 2000. "Fiscal Decentralization: A Remedy for Corruption?" Department of Economics, University of Illinois at Urbana-Champaign, Processed.

Bac, Mehmet and Parimal K. Bag (1998). "Corruption, collusion and implementation: A Hierarchial Design.” Mimeo, University of Liverpool.

Banfield, Edward (1975). "Corruption as Feature of Government Organization.” Journal of Law and Economics 18:587-695. 
Bardhan, Pranab (1997). “Corruption and development: A Review of Issues.” Journal Of Economic Literature 35(September):1320-46.

Bardhan, Pranab and Dilip Mookherjee (2000a, b). "Decentralizing Anti-Poverty Program Delivery in Developing Countries." Working Paper (University of California, Berkeley).

Batley, R. (1999). "The Role of Government in Adjusting Economies: An Overview of Findings.” International Development Department, University of Birmingham, Birmingham, Alabama.

Becker, Gary Stanley (1983). "A Theory of Competition Among Pressure Groups for Political Influence." Quarterly Journal of Economics XCVII (3): 371-400. , 1968. "Crime and Punishment: An Economic Approach.” Journal of Political Economy 76(2):169-217.

Becker, Gary Stanley and George Stigler (1974). "Law Enforcement, Malfeasance and the Compensation of Enforcers." Journal of Legal Studies 3:1-19.

Blanchard, Olivier and Andrei Shleifer (2000). "Federalism with and without political centralization: China versus Russia." Working Paper, National Bureau Of Economic Research. No. 7616(March):1-14.

Carbonara Emanuela (1999). Bureaucracy, Corruption and Decentralization. University of Bologna, Itlay, Department of Economics Working Paper no. 342/33.

Carillo, Juan D. (2000). 'Corruption in Hierarchies.' Annales D'economie Et De Statistique / Institut National De La Statistique Et Des Etudes Economiques (France) 59:37-61.

Chand, Sheetal K. and Karl O. Moene (1997). “Controlling Fiscal Corruption.” International Monetary Fund Working Paper WP/97/100.

Crook, Richard and James Manor (2000). Democratic Decentralization. OED Working Paper Series No. 11, Summer 2000, World Bank, Washington, DC.

De Mello, Luis and Matias Barenstein (2001). "Fiscal Decentralization and Governance - A Cross-Country Analysis." IMF Working Paper 01/71.

Fisman, Raymond and Roberta Gatti (2002). Decentralization and Corruption: Evidence Across Countries. Journal of Public Economics, 83, 325-345.

Fiszbein, Ariel (1997). Emergence of Local Capacity: Lessons from Colombia. World Development, 25(7), 1029-43.

Flatters, Frank and W. Bentley Macleod (1995). "Administrative Corruption and Taxation." International Tax and Public Finance 2:397-417.

Grossman, Gene M. and Elhanan Helpman (1994). "Protection for Sale." American Economic Review 84(4): 833-50. 
Gupta, Sanjeev, Hamid Davoodi and Erwin Tiongson (2000). "Corruption and the Provision of Health Care and Education Services.” International Monetary Fund Working Paper $00 / 116$.

Gupta, Sanjeev, Hamid Davoodi and Rosa Alosno-Terme (1998). "Does Corruption Affect Income Inequality and Poverty?” International Monetary Fund Working Paper 98/76.

Gurgur, Tugrul and Anwar Shah, 2002, "Localization and Corruption: Panacea or Pandora's Box?", in Ehtisham Ahmad and Vito Tanzi, eds., Managing Fiscal Decentralization, (London and New York: Routledge Press), pp. 46-67.

Guriev, Sergei (2003). "Red tape and corruption.” Discussion Paper, Centre for Economic Policy Research (U.K.) No. 3972:1-27. , 1999. A Theory of Informative Red Tape with an Application to Top-level Corruption.

Huther, Jeff and Anwar Shah (2000). "Anti-corruption Policies and Programs: A Framework for Evaluation", Policy Research Working Paper 2501 (Washington: World Bank). , 1998, "Applying a Simple Measure of Good Governance to the Debate on Fiscal Decentralization,” Policy Research Working Paper 1894 (Washington: World Bank).

Klitgaard, Robert E. (1991). "Gifts and Bribes.” In Richard Zeckhauser (Eds.) Strategy and Choice. MIT Press Cambridge, MA. , 1988. Controlling Corruption. Berkeley: University of California Press.

Kuncoro, Ari (2000). The Impact of Licensing Decentralization on Firm Location Choice: The Case of Indonesia. Faculty of Economics, University of Indonesia. Proceesed.

Lambsdorff, Johann (1999). Corruption in Empirical Research - A Review. Transparency International, processed.

Mauro, Paolo (1995). “Corruption and Growth.” Quarterly Journal of Economics 110(3):681-713.

Olowu, Dele (1993). Roots and Remedies of Government Corruption in Africa. Corruption and Reform, 7(3), 227-236.

Prud'homme, Remy (1994): “On the Dangers of Decentralization”, World Bank Policy Research Working Paper 1252, Washington: World Bank.

Rose-Ackerman, S. (1978). Corruption a Study in Political Economy. New York, San Francisco, London: Academic Press. , 1975. “The Economics of Corruption.” Journal of Public Economics 4 (February):187203.

Scharpf, Fritz W. (1997). Games Real Actors Play - Actor-Centered Institutionalism in Policy Research. Boulder, CO: Westview Print. 
Seabright, Paul (1996). Accountability and decentralization in government: An incomplete contracts model. European Economic Review, 40 (1), 61-89.

Shah, Anwar and Mark Schacter (2004). Combating Corruption. Look Before You Leap. Finance and Development, 41 (4, December), 40-43, Washington, DC: IMF

Shah, Anwar, Theresa Thompson, and Heng-fu Zou, 2004, "The Impact of Decentralization on Service Delivery, Corruption, Fiscal Management and Growth in Developing and Emerging Market Economies: A Synthesis of Empirical Evidence," CESifo Dice Report, A Quarterly Journal for Institutional Comparisons, Vol. 2 (Spring), pp. 10-14.

Shah, Anwar, (2005).On Getting the Giant to Kneel: Approaches to a Change in the Bureaucratic Culture. In Anwar Shah, editor, Fiscal Management. Public Sector Governance and Accountability Series, pp.211-229. Washington, DC: World Bank , 1999. Governing for Results in a Globalized and Localized World. The Pakistan Development Review, 38 (4), Part I, 385-431. , 1998. "Balance, Accountability, and Responsiveness: Lessons about Decentralization", World Bank Policy Research Working Paper Series 2021 (December).

Shleifer, Andrei and Roberth W. Vishny (1993). "Corruption.” Quarterly Journal of Economics 108:599-617. August 1993.

Tanzi, Vito (1995): "Fiscal Federalism and Decentralization: A Review of Some Efficiency and Macroecoomic Aspects", Annual World Bank Conference on Development Economics, pp.295-316.

Tanzi, Vito and Hamid Davoodi (1997). "Corruption, Public Investment, and Growth.” International Monetary Fund Working Paper 97/139.

Tirole, Jean (1986). "Hierarchies and Bureauracies: On the Role of Collusion in Organizations." Journal of Law Economics and Organization 2:181-214.

Tirole, Jean and Jean-Jacques Laffont (1988). 'Politics of government decision-making: a theory of regulatory capture.' Working Paper (Department of Economics, Massachusetts Institute of Technology) 506:1-48.

Tomaszewska, Ewa and Anwar Shah (2000). Phantom Hospitals, Ghost Schools and Roads to Nowhere: The Impact of Corruption on Public Service Delivery Performance in Developing Countries. Working Paper Operations Evaluation Department, World Bank. Treisman. Daniel S. (2000): “The Causes of Corruption: A Cross National Study”, Journal of Public Economics, June, 76(3):399-457. , (1999). After the Deluge: Regional Crises and Political Consolidation in Russia. Ann Arbor, Mich.: University of Michigan Press. 
Treisman, Daniel S. and Andrei Shleifer (2002). “A normal country.” Working Paper, National Bureau of Economic Research No. 10057(October):1-46.

Van Rijckeghem, Caroline and Beatrice Weder (2001). Bureaucratic Corruption and the Rate of Temptation: Do Low Wages in Civil Service Cause Corruption?” Journal of Development Economics 65:307-331.

Wade, Robert (1997). How infrastructure agencies motivate staff: Canal irrigation in India and the Republic of Korea. In Ashoka Mody (ed.), Infrastructure Strategies in East Asia, Washington, DC: World Bank.

Waller, Christopher J., Thierry A. Verdier and Roy Gardner (2002). "Corruption: Top-Down or Bottom-Up.” Economic Inquiry 40 (4):688-703.

Weinsgast, Barry (1995). “The Economic Role of Political Institutions: Markett Preserving Federalism and Economic Growth.” Journal of Law, Economics, and Organization 11:131.

Wildasin, David (1995): "Comment on 'Fiscal Federalism and Decentralization"”, Annual World Bank Conference on Development Economics, pp.323-328.

World Bank, 2004, Mainstreaming Anti-Corruption Activities in World Bank $\quad$ Assistance-A Review of Progress Since 1997 (Washington: World Bank).

Van Rijckeghem and Beatrice Weder (1997). "Corruption and the Role of Temptation: Do Low Wages in Civil Service Cause Corruption?” IMF Working Paper, WP/97/73.

Von Maravic, Patrick (2003). "How to Analyse Corruption in the Context of Public Management Reform?" Paper presented at the first meeting of the Study Group on Ethics and Integrity of Governance EGPA Conference. September 2003. Portugal.

\footnotetext{
1 The total number of countries have risen from 140 in 1975 to over 200 in 2004. In 2001, there are 24 federal countries with $25.4 \%$ of the world population with another 20 decentralized unitary countries with some federal features having $35 \%$ of world population.

2 This section draws upon Shah and Schacter (2005).

${ }^{3}$ For comprehensive surveys on corruption, see Jain (2001) and Aidt (2003).

${ }^{4}$ Following this line of thought, Lambsdorff et al. note that in fighting corruption from a NIE perspective policy makers should aim to "encourage betrayal among corrupt parties, to destabilize corrupt agreements, to disallow corrupt contracts to be legally enforced, to hinder the operation of corrupt middlemen and to find clearer ways of regulating conflicts of interest."
} 